\title{
Hydrosols from Rosmarinus officinalis, Salvia officinalis, and Cupressus sempervirens: Phytochemical Analysis and Bioactivity Evaluation
}

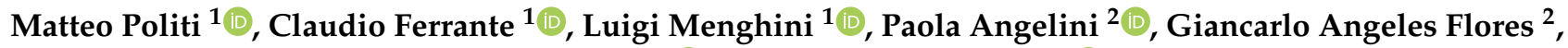 \\ Beatrice Muscatello $^{3,4}$, Alessandra Braca ${ }^{3,4, *(D)}$ and Marinella De Leo ${ }^{3,4}$ (D) \\ 1 Dipartimento di Farmacia, Botanic Garden "Giardino dei Semplici", Università di Chieti-Pescara, \\ Via Vestini 1, 66100 Chieti Scalo, Italy; matteo.politi@unich.it (M.P.); claudio.ferrante@unich.it (C.F.); \\ luigi.menghini@unich.it (L.M.) \\ 2 Dipartimento di Chimica, Biologia e Biotecnologia, Università di Perugia, Via del Giochetto 6, \\ 06122 Perugia, Italy; paola.angelini@unipg.it (P.A.); giancarlo.angelesflores@studenti.unipg.it (G.A.F.) \\ 3 Dipartimento di Farmacia, Università di Pisa, Via Bonanno 33, 56126 Pisa, Italy; \\ beatrice.muscatello@unipi.it (B.M.); marinella.deleo@unipi.it (M.D.L.) \\ 4 Centro per l'Integrazione della Strumentazione dell'Università di Pisa (CISUP), Lungarno Pacinotti 43, \\ 56126 Pisa, Italy \\ * Correspondence: alessandra.braca@unipi.it; Tel.: +39-050-221-9688
}

check for

updates

Citation: Politi, M.; Ferrante, C.; Menghini, L.; Angelini, P.; Flores, G.A.; Muscatello, B.; Braca, A.; De Leo, M. Hydrosols from Rosmarinus officinalis, Salvia officinalis, and Cupressus sempervirens:

Phytochemical Analysis and Bioactivity Evaluation. Plants 2022, 11, 349. https://doi.org/10.3390/ plants11030349

Academic Editor: Lígia R. Salgueiro

Received: 9 December 2021

Accepted: 23 January 2022

Published: 27 January 2022

Publisher's Note: MDPI stays neutral with regard to jurisdictional claims in published maps and institutional affiliations.

Copyright: (C) 2022 by the authors. Licensee MDPI, Basel, Switzerland. This article is an open access article distributed under the terms and conditions of the Creative Commons Attribution (CC BY) license (https:// creativecommons.org/licenses/by/ $4.0 /)$.
Abstract: The present work evaluates the aromatic waters of rosemary (Salvia rosmarinus Spenn. syn. Rosmarinus officinalis L.), sage (Salvia officinalis L.), and cypress (Cupressus sempervirens L.) obtained as innovative commercial products of a hydrodistillation process. All extracts were exhaustively analysed by GC-MS, ${ }^{1} \mathrm{H}-\mathrm{NMR}$, and LC-MS in order to evaluate potential metabolite fingerprint differences. GC-MS appears to be the most exhaustive technique for the qualitative identification of the single constituents, although in this case, the use of ${ }^{1} \mathrm{H}-\mathrm{NMR}$ and LC-MS techniques allowed some useful considerations in semi-quantitative terms. Antimycotic effects were studied against Tricophyton, Candida, and Arthroderma species, resulting in weak activity. The toxicological impact was partly evaluated in vitro by means of allelopathy and brine shrimp lethality. Cytotoxicity was investigated in human colon cancer cells (HCT116) and in hypothalamic cells (Hypo-E22) challenged with hydrogen peroxide. Sage and rosemary hydrosols were the most effective antimycotics, whereas all hydrosols displayed antiradical effects. Cytotoxic effects against HCT116 cells (at $500 \mu \mathrm{L} / \mathrm{mL}$ ) were related in silico to the endovanilloid TRPM8 and TRPV1 receptors. At lower concentrations $(5-50 \mu \mathrm{L} / \mathrm{mL})$, the hydrosols protected hypothalamic neurons Hypo-E22 cells from hydrogen peroxide-induced toxicity. The overall experience indicates that hydrolates are an important source of relevant phytochemicals with significant pharmacological potential.

Keywords: Rosmarinus officinalis; Salvia officinalis; Cupressus sempervirens; aromatic water; hydrosol; hydrolate; fingerprinting analysis; cytotoxicity; in silico analysis

\section{Introduction}

Aromatic waters, also known as hydrolates or hydrosols, are the aqueous phase obtained from the steam or hydrodistillation of different parts of aromatic plants, which separate from the essential oil phase at the end of the distillation process [1]. While the scientific literature on essential oils is relatively abundant, much less is known regarding aromatic waters [2]. Metabolite profiles of hydrolates may or may not qualitatively overlap with those of the corresponding essential oils, though they usually differ in quantitative terms. In a comparison between 44 hydrolates with the corresponding essential oils, it was found that in $42 \%$ of the cases, the main components of essential oils and hydrolates were different [3]. This trend was also observed in other cases [4-6], indicating the relevance of 
testing the biological activities of this kind of undervalued natural extract [7], which have been recently proposed as the main products of aromatic plant distillation [8].

It is known that the volatile profiles of hydrolates can vary depending not only on the origin of the plant materials but also on the applied analytical techniques and instrumental conditions used for the analysis [9]. Therefore, in this work, a full metabolomic platform based on GC-MS, LC-MS, and NMR techniques for the analysis of the aromatic waters obtained by hydrodistillation of the flowering aerial parts of rosemary (Salvia rosmarinus Spenn. syn. Rosmarinus officinalis L.) and sage (Salvia officinalis L.), as well as the cones of cypress (Cupressus sempervirens L.), was applied. Although these plants are well-known botanical species of the Mediterranean flora, literature data on their aromatic waters are rather scarce.

Borneole, camphor, 1,8-cineole, and verbenone appear to be the major compounds in the aromatic waters from rosemary grown in Corsica [6] and in Japan [10], although their relative amounts appear to be partially different; in fact, rosemary can be distinguished in different chemotypes including camphor, cineole, $\alpha$-pinene, and verbenone types [11]. Although most of the biological data on rosemary and other aromatic waters focus on their antimicrobial activities $[2,12,13]$, the potential beneficial properties on cognition and the cerebrovascular system of acute consumption of rosemary aromatic water on healthy adults have been recently assessed [14].

The aromatic water obtained from a sage sample collected and distilled in Turkey showed camphor, 1,8-cineole, $\alpha$ - and $\beta$-thujone, and borneole as major constituents [15]. Another aromatic water sample obtained from plant material collected in Morocco with a similar volatile profile showed poor antioxidant properties compared with other Mediterranean plant species hydrosols [16].

Despite the fact that the constituents of cypress cones have been investigated [17], as well as the corresponding essential oil profile [18], as far as we know, there are no literature data on the volatile constituents of the aromatic water of $C$. sempervirens; only the hydrosols of others Cupressus species, including C. lusitanica [19] and C. atlantica [20], were previously investigated.

Due to the low amount of literature data on the aromatic water from rosemary, sage, and cypress, the aim of the present work was to perform an in-depth phytochemical analysis based on headspace, solid phase microextraction coupled with gas chromatography-mass spectrometry (HS-SPME-GC-MS), ultra-high performance liquid chromatography coupled to a high-resolution mass spectrometry (UHPLC-HR-MS), and nuclear magnetic resonance (NMR) analyses. Moreover, ecotoxicological, antimycotic, cytotoxic, and protective effects induced by the aromatic waters were also investigated in different in vitro models, whereas a bioinformatics analysis was conducted to identify putative protein targets underlying the observed effects. The results supported the rationale for the pharmaceutical use of the present hydrosols.

\section{Results}

\subsection{HS-SPME-GC-MS of the Hydrosols}

Sampling of the volatile organic compounds (VOCs) in the headspace of the aromatic water was carried out by the SPME technique, followed by GC-MS analysis (Figures S1-S3 in Supplementary Materials). Table 1 lists all the identified compounds. The identification was obtained by comparing retention times with those of pure compounds, linear relative indices (LRI) to a series of $n$-hydrocarbons, and mass spectra against commercial (NIST 98 and ADAMS) and homemade libraries of mass spectra.

Oxygenated monoterpenes represented the most abundant class in all samples. In rosemary's hydrosol headspace, $70.4 \%$ of the compounds found were oxygenated monoterpenes, mainly 1,8 -cineole $(47.1 \%)$, camphor $(5.4 \%)$, borneol $(3.7 \%)$, verbenone $(2.8 \%)$, and linalool (2\%). Among the monoterpene hydrocarbons, camphene (3.9\%), $\beta$-pinene $(3.6 \%)$, and $\alpha$-pinene $(1.4 \%)$ were the most abundant, as in the essential oil composition [21-23]. 
Table 1. Total volatile organic compound (VOC) profiles for hydrolates of rosemary (R), sage (S), and cypress (C) by HS-SPME-GC-MS.

\begin{tabular}{|c|c|c|c|c|c|}
\hline \multirow[b]{2}{*}{ Compound } & \multirow[b]{2}{*}{$t_{\mathrm{R}}(\min )$} & \multirow[b]{2}{*}{ LRI } & \multicolumn{3}{|c|}{ Relative Content \% } \\
\hline & & & $\mathbf{R}$ & $\mathbf{S}$ & $\mathrm{C}$ \\
\hline Monoterpene hydrocarbons & & & 15.6 & 1.3 & 23.0 \\
\hline$\alpha$-pinene & 5.61 & 939 & 1.4 & 0.1 & 4.5 \\
\hline camphene & 5.94 & 953 & 3.9 & 0.1 & - \\
\hline thuja-2,4(10)-diene & 6.05 & 957 & 0.9 & - & - \\
\hline sabinene & 6.55 & 976 & - & - & 2.4 \\
\hline$\beta$-pinene & 6.69 & 980 & 3.6 & 0.8 & 0.2 \\
\hline myrcene & 7.03 & 991 & 1.9 & - & 0.9 \\
\hline$\alpha$-phellandrene & 7.47 & 1005 & 0.4 & - & 0.2 \\
\hline$\delta$-3-carene & 7.66 & 1011 & 0.4 & - & 4.9 \\
\hline$\alpha$-terpinene & 7.87 & 1018 & 0.6 & - & 0.9 \\
\hline p-cymene & 8.09 & 1026 & - & - & 1.4 \\
\hline limonene & 8.23 & 1031 & - & - & 2.4 \\
\hline$\gamma$-terpinene & 9.30 & 1062 & 1.4 & 0.2 & 1.4 \\
\hline terpinolene & 10.34 & 1088 & 1.1 & 0.1 & 3.8 \\
\hline Oxygenated monoterpenes & & & 70.4 & 93.7 & 73.9 \\
\hline 1,8-cineole (eucalyptol) & 8.64 & 1033 & 47.1 & 42.9 & 1.1 \\
\hline linalool & 10.83 & 1098 & 2.0 & - & 0.4 \\
\hline filifolone & 10.95 & 1108 & 1.6 & - & - \\
\hline$\alpha$-thujone & 11.13 & 1110 & - & 24.3 & 0.4 \\
\hline exo-fenchol & 11.26 & 1112 & - & - & 0.2 \\
\hline$\beta$-thujone & 11.53 & 1114 & - & 14.7 & 0.5 \\
\hline cis- $p$-menth-2-en-1-ol & 11.57 & 1121 & - & - & 1.6 \\
\hline$\alpha$-campholenal & 11.77 & 1125 & 0.2 & - & - \\
\hline trans-pinocarveol & 12.24 & 1139 & 0.2 & - & - \\
\hline trans- $p$-menth-2-en-1-ol & 12.27 & 1140 & - & - & 0.9 \\
\hline camphor & 12.58 & 1143 & 5.4 & 8.9 & 1.1 \\
\hline camphene hydrate & 12.63 & 1148 & - & - & 0.3 \\
\hline trans-pinocamphone & 13.15 & 1160 & 0.2 & - & - \\
\hline pinocarvone & 13.24 & 1162 & 0.6 & - & - \\
\hline borneol & 13.44 & 1165 & 3.7 & 1.9 & 1.6 \\
\hline cis-pinocamphone & 13.74 & 1173 & 1.0 & - & - \\
\hline 4-terpineol & 13.85 & 1177 & 0.7 & 0.6 & 44.5 \\
\hline$\alpha$-terpineol & 14.38 & 1190 & 0.8 & 0.2 & 3.4 \\
\hline cis-piperitol & 14.55 & 1193 & - & - & 0.3 \\
\hline myrtenol & 14.62 & 1193 & 0.2 & - & - \\
\hline trans-piperitol & 15.05 & 1205 & - & - & 0.1 \\
\hline verbenone & 15.20 & 1206 & 2.8 & - & 0.1 \\
\hline methyl carvacrol & 16.59 & 1244 & - & - & 0.3 \\
\hline piperitone & 16.98 & 1252 & - & - & 0.4 \\
\hline geraniol & 17.04 & 1255 & 0.4 & - & - \\
\hline bornyl acetate & 18.40 & 1285 & 3.4 & 0.2 & 3.5 \\
\hline$\gamma$-terpinyl acetate & 20.60 & 1341 & - & - & 2.6 \\
\hline$\alpha$-terpinyl acetate & 20.99 & 1350 & - & - & 10.6 \\
\hline geranyl acetate & 22.44 & 1383 & 0.1 & - & - \\
\hline Sesquiterpene hydrocarbons & & & 0.7 & 4.3 & 2.3 \\
\hline$\alpha$-cubebene & 20.98 & 1351 & - & 0.1 & - \\
\hline$\alpha$-copaene & 22.06 & 1376 & - & 0.2 & - \\
\hline$\alpha$-cedrene & 23.55 & 1409 & - & - & 0.7 \\
\hline$\beta$-caryophyllene & 23.84 & 1418 & 0.6 & 2.7 & 0.7 \\
\hline aromadendrene & 24.61 & 1439 & - & 0.2 & - \\
\hline$\alpha$-humulene & 25.21 & 1454 & 0.1 & 0.6 & 0.2 \\
\hline$\gamma$-murolene & 26.15 & 1477 & - & 0.2 & - \\
\hline germacrene D & 26.30 & 1480 & - & - & 0.6 \\
\hline
\end{tabular}


Table 1. Cont.

\begin{tabular}{cccccc}
\hline & & \multicolumn{3}{c}{ Relative Content \% } \\
\hline Compound & $\boldsymbol{t}_{\mathbf{R}}(\mathbf{m i n})$ & LRI & $\mathbf{R}$ & $\mathbf{S}$ & $\mathbf{C}$ \\
\hline valencene & 26.86 & 1491 & - & 0.1 & - \\
$\delta$-cadinene & 27.99 & 1524 & - & 0.2 & - \\
\hline Oxygenated sesquiterpenes & & & - & 0.3 & 0.6 \\
\hline caryophyllene oxide & 30.23 & 1581 & - & 0.1 & - \\
$\quad$ viridiflorol & 30.56 & 1590 & - & 0.2 & - \\
$\quad$ cedrol & 30.91 & 1596 & - & - & 0.6 \\
\hline Total identified & & & 86.7 & 99.6 & 99.7 \\
\hline
\end{tabular}

In sage's hydrosol headspace, oxygenated monoterpenes accounted for $93.7 \%$ of the total VOC content, with the predominance of 1,8-cineole (42.9\%), $\alpha$-thujone (24.3\%), $\beta$-thujone $(14.7 \%)$, and camphor $(8.9 \%)$. The main components of the monoterpene and sesquiterpene hydrocarbons were $\beta$-pinene and $\beta$-caryophyllene, respectively. As reported in the literature, these compounds were also the major components in the essential oil from sage [24-26].

The aromatic water obtained from cypress cones contained $73.8 \%$ of oxygenated monoterpenes, mainly 4 -terpineol $(44.5 \%)$ and $\alpha$-terpinyl acetate $(10.6 \%), 23 \%$ of monoterpene hydrocarbons with $4.9 \%$ of $\delta$-3-carene, $4.5 \%$ of $\alpha$-pinene, and $2.4 \%$ of both sabinene and limonene and a small content of sesquiterpene hydrocarbons (cedrene, $\beta$-caryophyllene, and germacrene D). In this case, the composition was quite different from the essential oil, which is mainly rich in $\alpha$-pinene, 1,8-cineole, camphor, borneol, and $\alpha$-terpineol [27-29].

\section{2. ${ }^{1} H-N M R$ and UHPLC-HR-MS Analyses of the Hydrosols}

In accordance with our previous work [8], ${ }^{1} \mathrm{H}-\mathrm{NMR}$ spectra with the suppression of the water signal were carried out for the hydrolate analysis and reported in Figure 1. Rosemary hydrosol spectrum showed the presence of signals attributable to verbenone $(\delta 5.82,2.88,2.63,2.17,2.08,1.52$, and 0.98$), 1,8$-cineole $(\delta 2.08,1.66,1.61,1.26$, and 1.05$)$ and camphor $(\delta 2.08,1.53,0.99,0.90$, and 0.85$)$; sage hydrolate displayed signals for 1,8-cineole $(\delta 2.05,1.66,1.59,1.26$, and 1.05$)$, camphor $(\delta 2.02,1.55,0.97,0.90$, and 0.85$)$, and, in a lesser amount, $\alpha / \beta$-thujone $(\delta 2.72,2.44,2.16,1.05,0.98$, and 0.93$)$, while ${ }^{1} \mathrm{H}$-NMR spectrum of cypress hydrosol showed few signals, assignable only to 4-terpineol $(\delta 1.91,1.67,0.92$, and 0.90) [30-34].

The chemical profiles of rosemary, sage, and cypress hydrolates, investigated by means of UHPLC-HR-MS, are reported in Figure 2.

In all hydrolates, the major components were represented by volatile compounds, according to results obtained by GC-MS analyses, while no phenolics or other non volatile constituents were recorded. In particular, oxygenated monoterpenes were found, such as verbenone, borneol, linalool, 4-terpineol, $\alpha$-terpineol, camphor, 1,8-cineole, and piperitone. The distribution of compounds in the hydrolates, together with MS data registered in positive ion mode, are reported in Table 2.

All molecules were identified by comparison of full and fragmentation mass spectra with those of reference standards, except for piperitone, which was tentatively attributed by analysis of MS/MS data. In full MS experiments, the monoterpene alcohols borneol, linalool, 4-terpineol, $\alpha$-terpineol, and 1,8-cineole showed protonated molecular ions at $\mathrm{m} / \mathrm{z}$ 137.1323 as precursor ions after the loss of a water molecule $\left(\left[\mathrm{M}+\mathrm{H}-\mathrm{H}_{2} \mathrm{O}\right]^{+}\right.$in the ESI source). These molecules also showed very similar fragmentation pathways; thus, the comparison of retention times with reference standards was useful for their discrimination. Camphor, $\alpha / \beta$-thujone, and piperitone are monoterpene ketones showing in the full ESI-MS the same protonated molecular ion at $m / z$ 153.127. Fragmentation experiments generated very 
similar product ions, but with different abundance (Table 2), which could be diagnostic for the differentiation of the three components. Some small peaks remained unidentified.

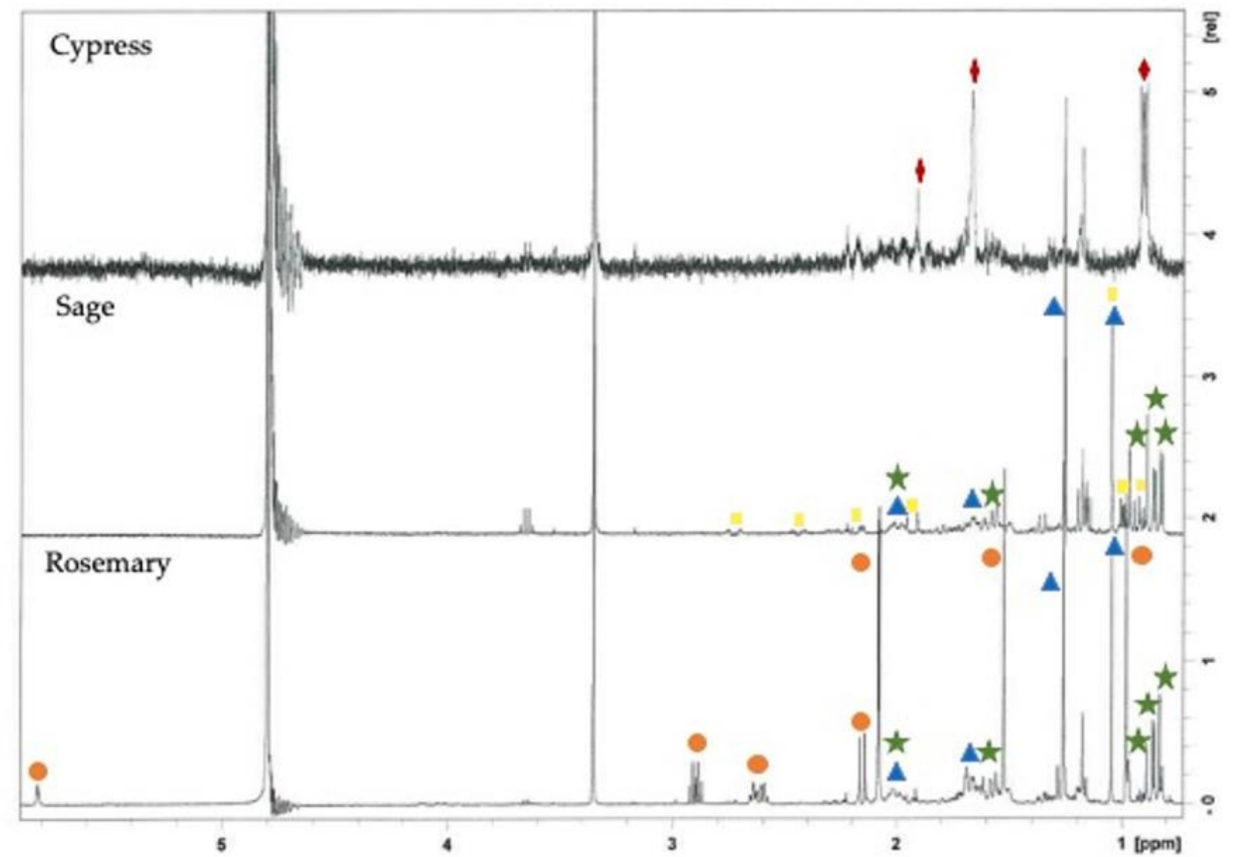

verbenone $\quad \Delta$ 1,8-cineole $\quad \star$ camphor $\alpha / \beta$-thujone $\quad \Delta$-terpineol

Figure 1. ${ }^{1} \mathrm{H}-\mathrm{NMR}$ spectra of rosemary, sage, and cypress hydrolates.

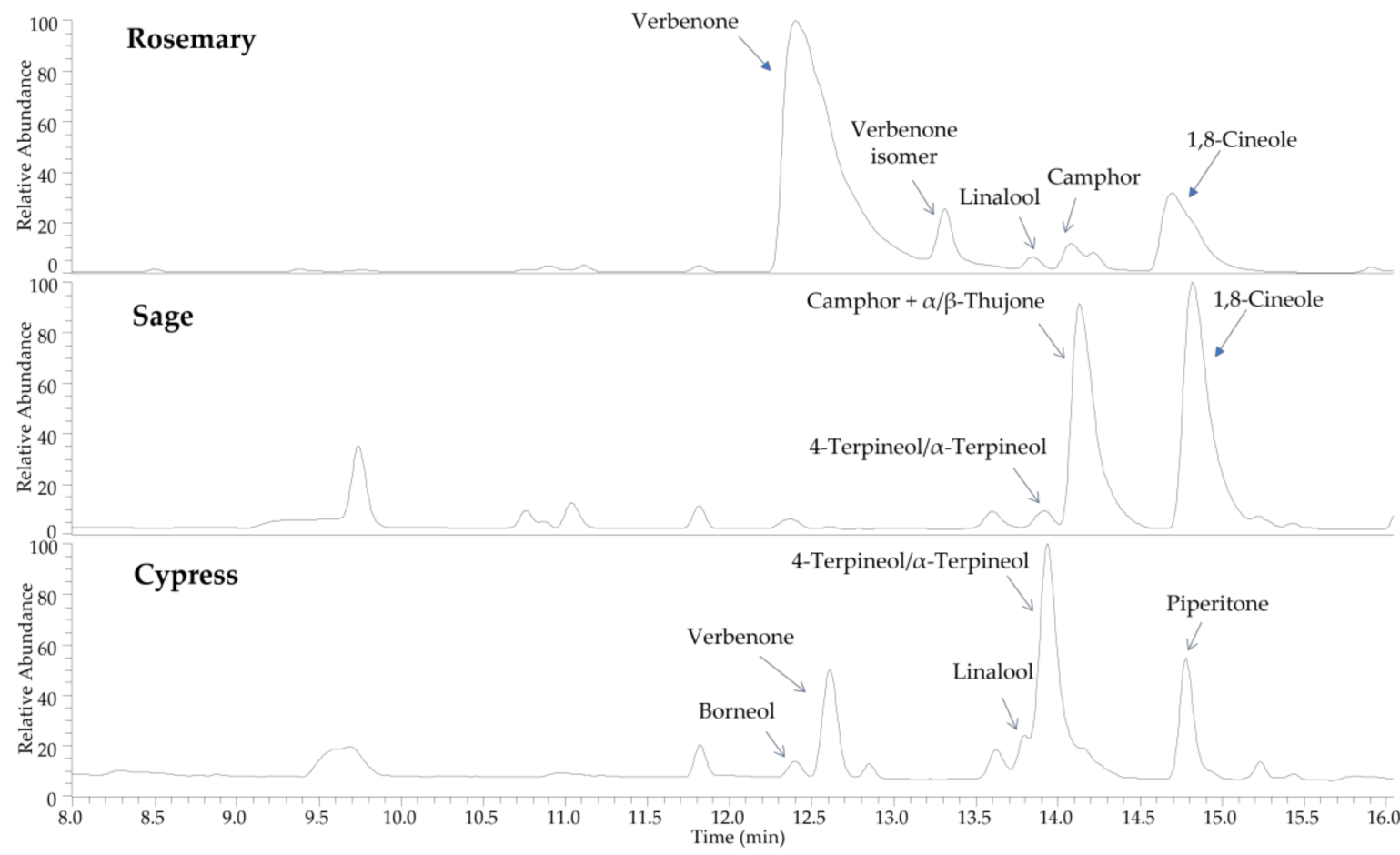

Figure 2. Chemical profiles (total ion current) of rosemary, sage, and cypress hydrolates obtained by UHPLC-HR-ESI-MS analysis. 
Table 2. Chromatographic ( $t_{\mathrm{R}}$, retention time) and HR-ESI-MS/MS data of compounds identified in hydrolates of rosemary (R), sage (S), and cypress (C).

\begin{tabular}{|c|c|c|c|c|c|c|c|c|}
\hline Compound ${ }^{a}$ & $\begin{array}{c}t_{R} \\
(\min )\end{array}$ & $\begin{array}{l}\text { Precursor Ion } \\
(m / z)\end{array}$ & $\begin{array}{c}\text { HR(+ESI)-MS/MS } \\
\text { Product Ions } \\
(m / z)\end{array}$ & $\begin{array}{l}\text { Molecular } \\
\text { Formula }\end{array}$ & $\begin{array}{l}\text { Exper. } \\
\text { Mass }\end{array}$ & $\begin{array}{l}\text { Theor. } \\
\text { Mass }\end{array}$ & $\begin{array}{l}\text { Error } \\
(\mathrm{ppm})\end{array}$ & Hydrolate \\
\hline Verbenone & 12.4 & $\begin{array}{c}151.1116 \\
\left([\mathrm{M}+\mathrm{H}]^{+}\right)\end{array}$ & $123.08, \mathbf{1 0 9 . 0 7}$ & $\mathrm{C}_{10} \mathrm{H}_{14} \mathrm{O}$ & 151.1116 & 151.1117 & -0.66 & $\mathrm{R}, \mathrm{C}$ \\
\hline Borneol & 13.6 & $\begin{array}{c}137.1324 \\
\left(\left[\mathrm{M}+\mathrm{H}-\mathrm{H}_{2} \mathrm{O}\right]^{+}\right)\end{array}$ & 109.10, 95.09, 81.07 & $\mathrm{C}_{10} \mathrm{H}_{18} \mathrm{O}$ & 137.1324 & 137.1325 & -0.73 & $\mathrm{C}$ \\
\hline Linalool & 13.8 & $\begin{array}{c}137.1323 \\
\left(\left[\mathrm{M}+\mathrm{H}-\mathrm{H}_{2} \mathrm{O}\right]^{+}\right)\end{array}$ & $109.10,95.09,81.07$ & $\mathrm{C}_{10} \mathrm{H}_{18} \mathrm{O}$ & 137.1323 & 137.1325 & -1.46 & $\mathrm{R}, \mathrm{C}$ \\
\hline $\begin{array}{l}\text { 4-Terpineol/ } \alpha \text { - } \\
\text { Terpineol }\end{array}$ & 13.9 & $\begin{array}{c}137.1323 \\
\left(\left[\mathrm{M}+\mathrm{H}-\mathrm{H}_{2} \mathrm{O}\right]^{+}\right)\end{array}$ & $109.10,95.09,81.07$ & $\mathrm{C}_{10} \mathrm{H}_{18} \mathrm{O}$ & 137.1323 & 137.1325 & -1.46 & $S, C$ \\
\hline Camphor & 14.1 & $\begin{array}{c}153.1271 \\
\left([\mathrm{M}+\mathrm{H}]^{+}\right)\end{array}$ & $135.12,109.10,97.07$ & $\mathrm{C}_{10} \mathrm{H}_{16} \mathrm{O}$ & 153.1271 & 153.1274 & -1.96 & $\mathrm{R}, \mathrm{S}$ \\
\hline$\alpha / \beta$-Thujone & 14.2 & $\begin{array}{c}153.1272 \\
\left([\mathrm{M}+\mathrm{H}]^{+}\right)\end{array}$ & $135.12,109.10,97.07$ & $\mathrm{C}_{10} \mathrm{H}_{16} \mathrm{O}$ & 153.1272 & 153.1274 & -1.31 & S \\
\hline $\begin{array}{l}\text { 1,8-Cineole } \\
\text { (Eucalyptol) }\end{array}$ & 14.7 & $\begin{array}{c}137.1323 \\
\left(\left[\mathrm{M}+\mathrm{H}-\mathrm{H}_{2} \mathrm{O}\right]^{+}\right)\end{array}$ & 109.10, 95.09, 81.07 & $\mathrm{C}_{10} \mathrm{H}_{18} \mathrm{O}$ & 137.1323 & 137.1325 & -1.46 & $\mathrm{R}, \mathrm{S}$ \\
\hline Piperitone & 14.8 & $\begin{array}{c}153.1271 \\
\left([\mathrm{M}+\mathrm{H}]^{+}\right)\end{array}$ & $\begin{array}{c}135.12,109.10,97.07 \\
\mathbf{8 1 . 0 7}, 71.05\end{array}$ & $\mathrm{C}_{10} \mathrm{H}_{16} \mathrm{O}$ & 153.1272 & 153.1274 & -1.31 & $\mathrm{C}$ \\
\hline
\end{tabular}

\subsection{Biological Studies of the Hydrosols}

2.3.1. Allelopathy Test

The effects of hydrosol dilution on the seed germination of three lettuce varieties are reported in Figure 3. The allelopathy test revealed intrinsic differences related to the physiology of the germination process, as well as sensitivity to the treatment between the different tested varieties. The variety Canasta was characterized by delayed germination; after 4 days, only half of the tested seeds showed emergent radicles while being less sensitive to the presence of hydrosols in the soaking solution. Only the rosemary hydrosol at the highest tested concentration completely inhibited the germination of the Canasta variety and other varieties as well. The germination of the Romana variety was inhibited by all hydrosols with $0 \%$ germination in the presence of sage or rosemary. Weaker inhibition was due to the presence of cypress that reduced the germination from $90-100 \%$ of the control to $10-50 \%$. At higher dilution (1/100), sage and cypress lost their inhibitory effect $(100 \%$ germination), while rosemary was still completely active $(0 \%)$. The Lollo Bionda variety was the most sensitive to the presence of hydrosols, with complete or strong germination inhibition (germination range 0-20\%), which was revealed for all tested samples at all dilutions. The hydrosol obtained from sage distillation was the most biocompatible, at least if applied diluted 100 fold, with no or partial effects on germination rate. Conversely, the rosemary hydrosol revealed a strong and broad spectrum of inhibitory effects on seed germination. These effects suggested cautions in the use of this extract without an appropriate dilution while remaining open to innovative strategies to investigate nonfood applications, such as selective herbicides.

\subsubsection{Brine Shrimp Lethality Test}

The potential toxic effects of the hydrosols added to the medium were evaluated in the ecotoxicological context using Artemia salina newborns. After a $24 \mathrm{~h}$ treatment, the effects of different concentrations of tested samples were evaluated and expressed as percentage mortality compared to the control seawater group. Data reported in Figure 4 showed that hydrosols are biocompatible at $100 \mu \mathrm{L} / \mathrm{mL}$ compared to the artificial seawater group. Cypress and sage showed a limited increase of mortality (mean value 30\% and 26\%, respectively) at higher concentrations, although this effect was not statistically significant 
compared to the control group. Only the rosemary hydrosol highlighted potential toxicity (mean mortality $95 \%$ ), although at the highest tested concentration $(500 \mu \mathrm{L} / \mathrm{mL})$, thus suggesting that a simple dilution of the product was sufficient to guarantee environmental safety. The present data agreed with the allelopathy test results, confirming the rosemary hydrosol as the most active.
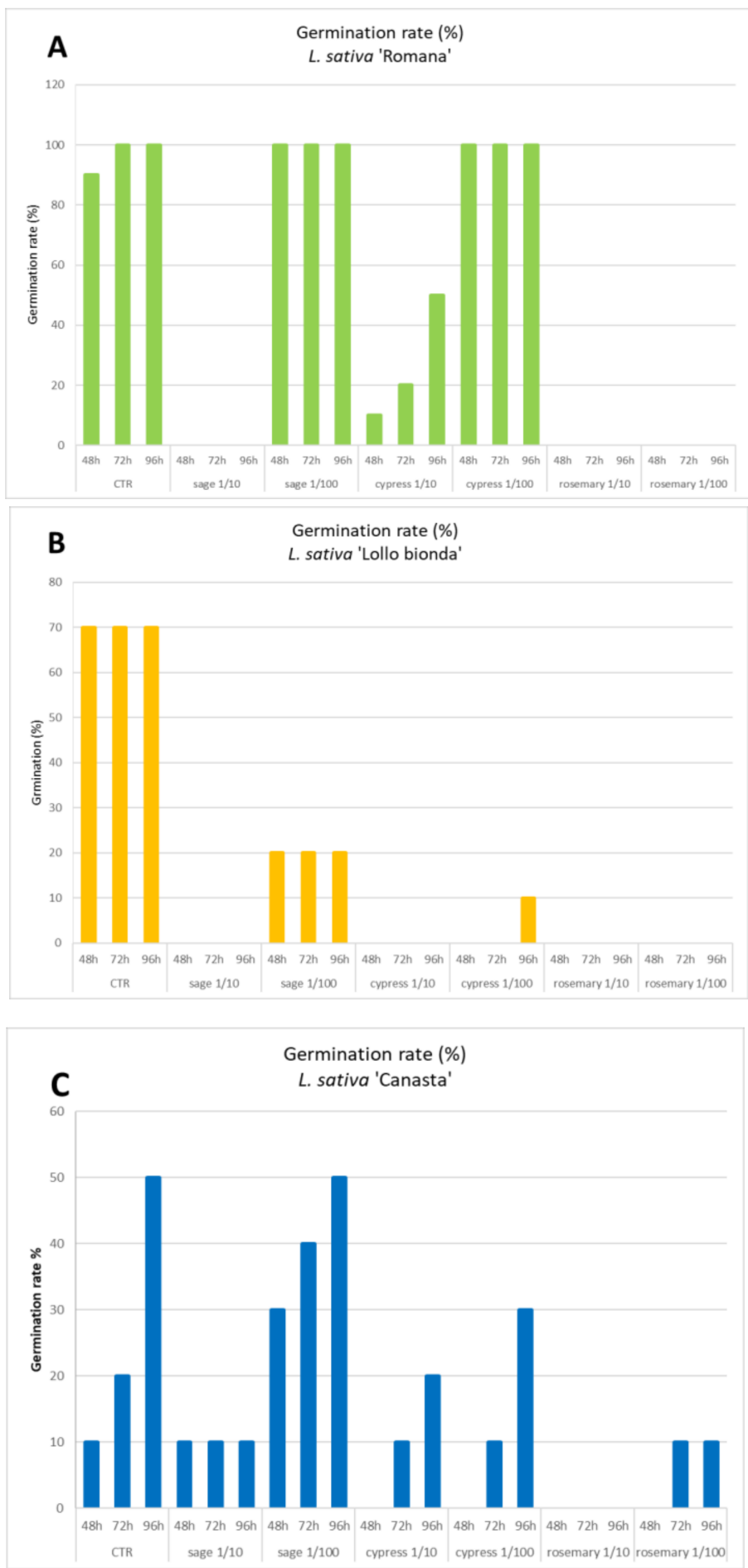

Figure 3. Allelopathic effects of supplementation of hydrosols in the soaking water used for seed germination of $L$. sativa varieties, namely Romana, Lollo Bionda, and Canasta (panels (A-C), respectively). Effects were monitored at 48, 72, and $96 \mathrm{~h}$ and the germination percentage was registered in the control (CTR, distilled water) and treated groups with two hydrosol dilutions. Data are mean values of four independent experiments. 


\section{Brine shrimp lethality test}

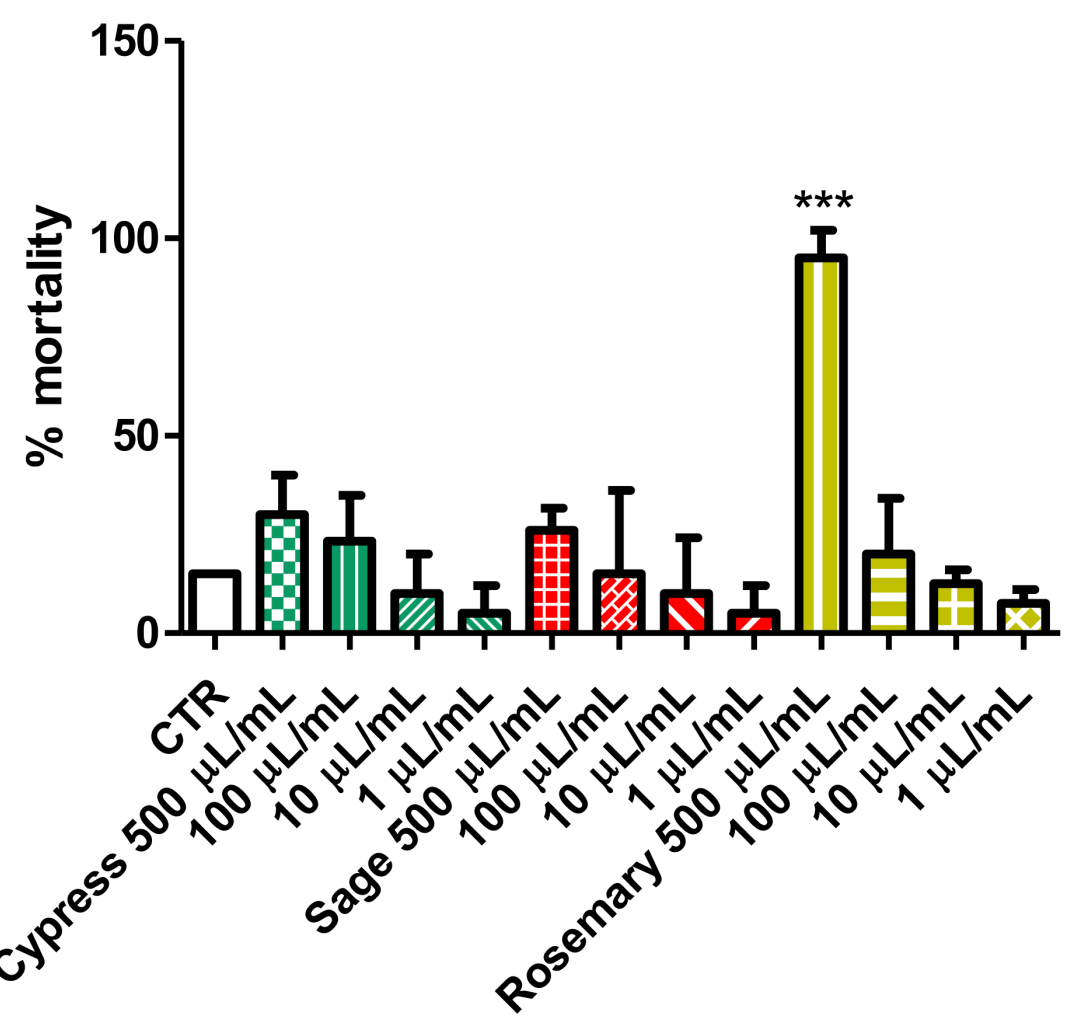

Figure 4. Brine shrimp lethality test. Effects of supplementation of hydrosols in artificial water used to breed newborn Artemia salina. Effects were monitored after $24 \mathrm{~h}$ treatment, and the mortality percentage was recorded in treated and control (CTR-artificial seawater) groups. Data are mean values \pm S.D. of triplicate experiments. ANOVA, $p<0.001 ;{ }^{* * *} p<0.01$ vs. control untreated group.

\subsubsection{Antifungal Activity}

The antifungal activity of the hydrosols is reported in Table 3; it is also presented in comparison with the reference drugs fluconazole and griseofulvin. Among the tested samples, the rosemary and sage hydrosols displayed the best antimycotic profile, with MIC values in the range of 7.81-62.5 $\mu \mathrm{L} / \mathrm{mL}$. The MIC values demonstrated an intrinsic weak antifungal activity compared to the reference drugs, while considering the dilution and the aqueous nature of the tested hydrosols, the detected activity could result in interest for a wide range of applications. Intriguingly, the strain sensitivity was similar, at least from a qualitative point of view.

Table 3. Minimal inhibitory concentrations (MICs) of aromatic waters against yeast and dermatophyte strains.

\begin{tabular}{|c|c|c|c|c|c|c|c|c|c|}
\hline & & & & & MIC* & & & & \\
\hline Fungal Strain & $\begin{array}{l}\text { Trichophyton } \\
\text { mentagrophytes } \\
\text { (CCF 4823) }\end{array}$ & $\begin{array}{l}\text { Trichophyton } \\
\text { tonsurans } \\
\text { (CCF 4834) }\end{array}$ & $\begin{array}{l}\text { Trichophyton } \\
\text { rubrum } \\
\text { (CCF 4879) }\end{array}$ & $\begin{array}{l}\text { Trichophyton } \\
\text { erinacei } \\
\text { (CCF 5930) }\end{array}$ & $\begin{array}{c}\text { Arthroderma } \\
\text { crocatum } \\
\text { (CCF 5300) }\end{array}$ & $\begin{array}{l}\text { Arthroderma } \\
\text { quadrifidum } \\
\text { (CCF 5792) }\end{array}$ & $\begin{array}{c}\text { Arthroderma } \\
\text { gypseum } \\
\text { (CCF 6261) }\end{array}$ & $\begin{array}{c}\text { Candida } \\
\text { albicans } \\
\text { (YEPGA 6138) }\end{array}$ & $\begin{array}{c}\text { Candida } \\
\text { tropicalis } \\
\text { (YEPGA 6184) }\end{array}$ \\
\hline \multicolumn{10}{|l|}{ Hydrosol } \\
\hline Cypress & $\begin{array}{c}99.2 \\
(62.5-125)\end{array}$ & $\begin{array}{c}39.4 \\
(31.3-62.5)\end{array}$ & $\begin{array}{c}397.0 \\
(250-500)\end{array}$ & $\begin{array}{c}397.0 \\
(250-500)\end{array}$ & $\begin{array}{c}24.8 \\
(15.6-31.3)\end{array}$ & $\begin{array}{c}39.4 \\
(31.3-62.5)\end{array}$ & $\begin{array}{c}198.4 \\
(125-250)\end{array}$ & $\begin{array}{c}49.6 \\
(31.3-62.5)\end{array}$ & $\begin{array}{c}78.7 \\
(62.5-125)\end{array}$ \\
\hline Rosemary & $\begin{array}{c}12.4 \\
(7.8-15.6)\end{array}$ & $\begin{array}{c}19.7 \\
(15.6-31.3)\end{array}$ & $\begin{array}{c}24.8 \\
(15.6-31.3)\end{array}$ & $\begin{array}{c}315.0 \\
(250-500)\end{array}$ & $\begin{array}{c}39.4 \\
(31.3-62.5)\end{array}$ & $\begin{array}{c}24.8 \\
(15.6-31.3)\end{array}$ & $\begin{array}{c}157.5 \\
(125-250)\end{array}$ & $\begin{array}{c}19.7 \\
(15.6-31.3)\end{array}$ & $\begin{array}{c}24.8 \\
(31.3-62.5)\end{array}$ \\
\hline Sage & $\begin{array}{c}19.7 \\
(15.6-31.3)\end{array}$ & $\begin{array}{c}24.8 \\
(15.6-31.3)\end{array}$ & $\begin{array}{c}24.8 \\
(15.6-31.3)\end{array}$ & $\begin{array}{c}397.0 \\
(250-500)\end{array}$ & $\begin{array}{c}49.6 \\
(31.3-62.5)\end{array}$ & $\begin{array}{c}99.2 \\
(62.5-125)\end{array}$ & $\begin{array}{c}315.0 \\
(250-500)\end{array}$ & $\begin{array}{c}19.7 \\
(15.6-31.3)\end{array}$ & $\begin{array}{c}24.8 \\
(15.6-31.3)\end{array}$ \\
\hline Fluconazole & $>16$ & 2 & 8 & $>16$ & 8 & $>16$ & $>16$ & 2 & 4 \\
\hline Griseofulvin & 1 & 0.125 & 2 & 0.25 & $>8$ & $>8$ & $>8$ & $>8$ & $>8$ \\
\hline
\end{tabular}

* MIC values are reported as geometric means of 3 independent replicates $(n=3)$. MIC range concentrations $(\mu \mathrm{L} / \mathrm{mL})$ are reported within brackets. MIC values of reference drugs are expressed as $\mu \mathrm{g} / \mathrm{mL}$. 
Trichophyton erinacei and Arthroderma gypseum were resistant to tested hydrosols, while all other strains were inhibited at concentrations lower than $100 \mu \mathrm{L} / \mathrm{mL}$.

\subsubsection{Cell Viability and Neuroprotective Effect}

The effects of the hydrosol supplementation of the culture media were tested on the colorectal cancer HCT116 cell line. As reported in Figure 5, after 24 h, only the highest concentration demonstrated alterations in cell viability, which was significantly reduced, at values lower than $50 \%$, in the presence of rosemary and sage. No significant effect (within the range $85-101 \%$ ) on cell viability was recorded at the lowest concentrations (100 and $50 \mu \mathrm{L} / \mathrm{mL}$ ), thus supporting the good biocompatibility of the tested extracts. Noteworthy, the hydrosol from cypress was also well tolerated by cells at $500 \mu \mathrm{L} / \mathrm{mL}$.

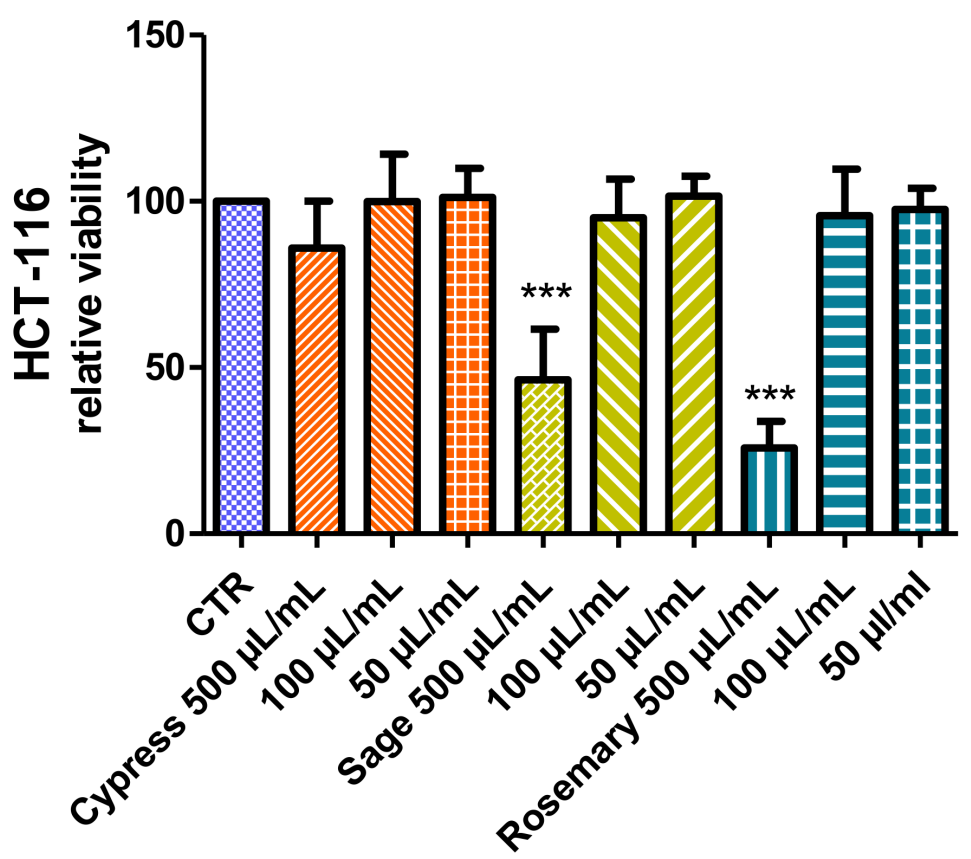

Figure 5. Anti-proliferative effects induced by the hydrosols. MTT assay was conducted on HCT116 cells exposed to hydrosols $(50-500 \mu \mathrm{L} / \mathrm{mL})$ for $24 \mathrm{~h}$. ANOVA, $p<0.001$; ${ }^{* * *} p<0.01$ vs. control untreated group.

In order to further explore potential biological effects, the biocompatibility of extracts was investigated on hypothalamic cells (Hypo-E22), which was also used as an experimental model for unravelling neuroprotective effects. Hydrosols were tested in the concentration range of 5-50 $\mu \mathrm{L} / \mathrm{mL}$, and no effect was detected on cell viability (Figure 6). Only the sage hydrosol showed a viability reduction that appeared concentration-dependent; however, even at the highest tested concentration, the percentage viability was higher than $70 \%$ compared to the control group (namely $81 \%$ at $50 \mu \mathrm{L} / \mathrm{mL}$ ). This viability limit is commonly accepted as an index of biocompatibility.

From the present findings, the highest concentration $(50 \mu \mathrm{L} / \mathrm{mL})$ was considered well tolerated by Hypo-E22 cells and subsequently tested as a sub-toxic concentration to explore the protective effects against the neurotoxicity induced by exogenous stimulus (hydrogen peroxide $300 \mu \mathrm{M}$ ). Data in Figure 7 showed a strong reduction of cell viability induced by hydrogen peroxide. The effects can be partially but significantly reverted by preventive treatment with hydrosols, which were effective in contrasting and preventing the toxicity induced by the oxidative stimulus. In particular, rosemary and sage were more effective in blunting the hydrogen peroxide-induced toxicity, thus restoring the basal viability levels. 

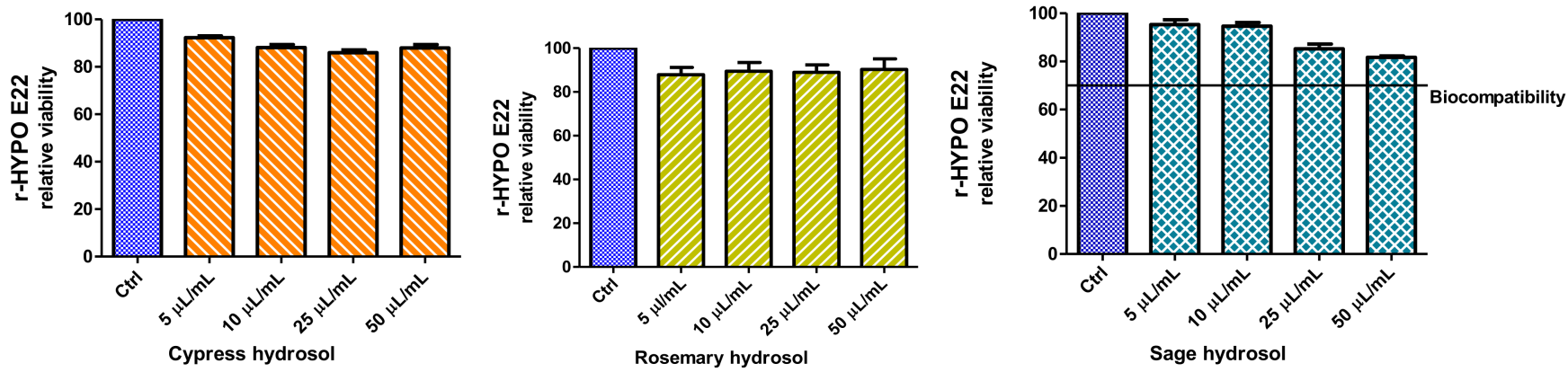

Figure 6. Null effect of hydrosols on hypothalamic neurons. MTT assay was conducted on hypothalamic Hypo-E22 cells exposed to the hydrosols $(5-50 \mu \mathrm{L} / \mathrm{mL})$ for $24 \mathrm{~h}$.

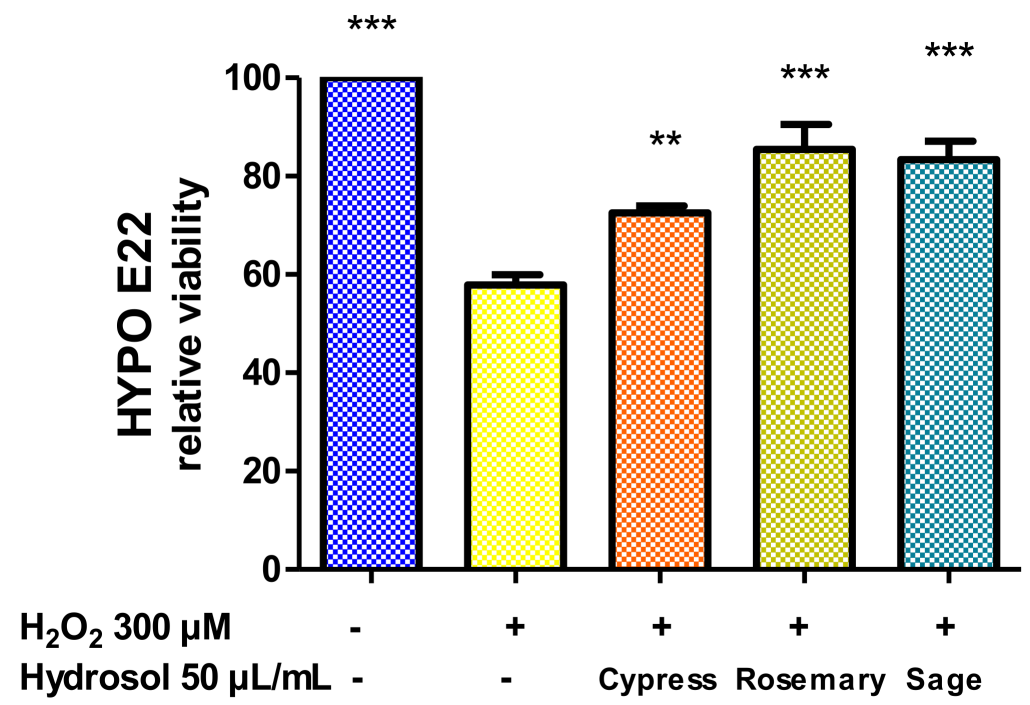

Figure 7. MTT assay of hypothalamic Hypo-E22 cells exposed to hydrosols $(50 \mu \mathrm{L} / \mathrm{mL})$ for $24 \mathrm{~h}$ challenged with $300 \mu \mathrm{M} \mathrm{H}_{2} \mathrm{O}_{2}$. ANOVA, $p<0.001$; $^{* *} p<0.01$, ${ }^{* * *} p<0.05$ vs. control group.

\subsubsection{Antioxidant Effect}

In order to explore the intrinsic antioxidant activity of hydrosols, samples were tested for their ability to inhibit the substrate de-coloration induced by horseradish enzyme activated by hydrogen peroxide. The resulting data are reported in Table 4 and highlighted only a partial effect (19.53-31.58\% inhibition).

Table 4. Inhibition of horseradish peroxidase (HRP).

\begin{tabular}{cccc}
\hline & \multicolumn{3}{c}{ Hydrosol } \\
\cline { 2 - 4 } & Cypress & Rosemary & Sage \\
\hline HRP \% inhibition & $25.94 \pm 1.84$ & $19.53 \pm 1.58$ & $31.58 \pm 2.04$ \\
\hline
\end{tabular}

\subsubsection{In Silico Analysis}

Finally, the terpenes from hydrosols were also studied through the bioinformatics platform STITCH in order to predict putative proteins underlying the observed effects on cell viability. The target component and gene ontology analyses pointed to the modulation of endovanilloid receptors (thermoception pathway, GO: 0050955) by different terpene compounds, namely camphor, geraniol, 1,8-cineole, and fenchol (Figure 8). 
A

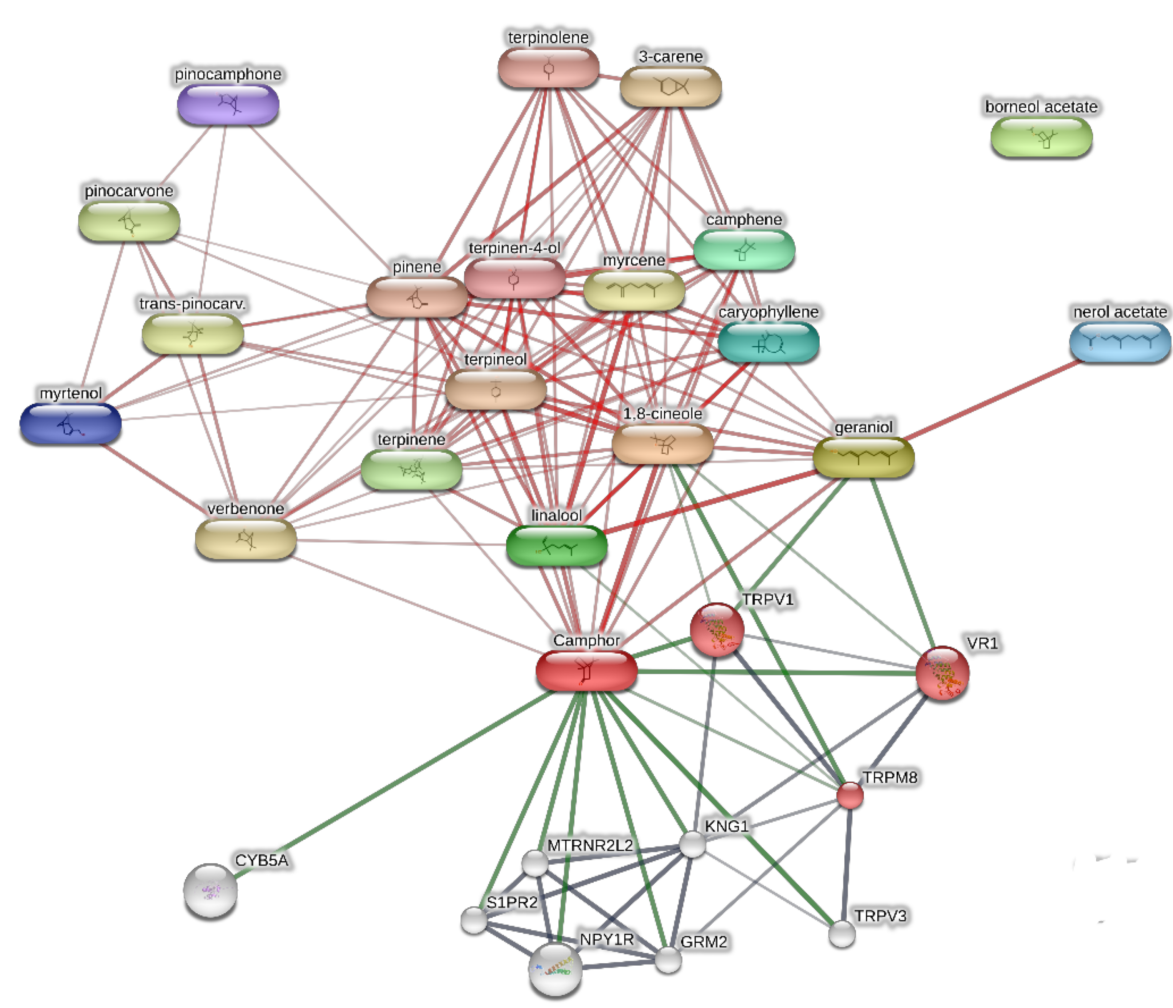

B

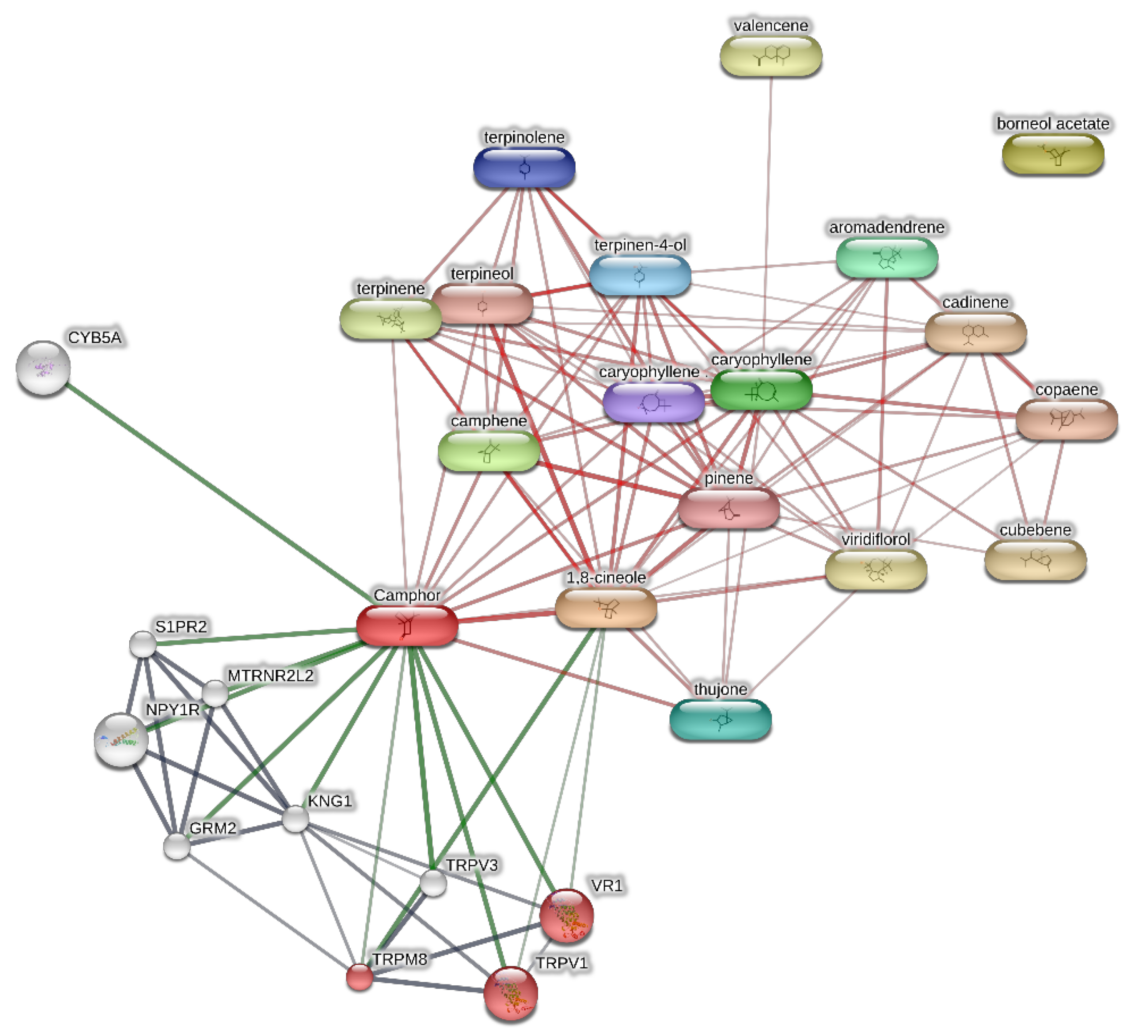

Figure 8. Cont. 
C

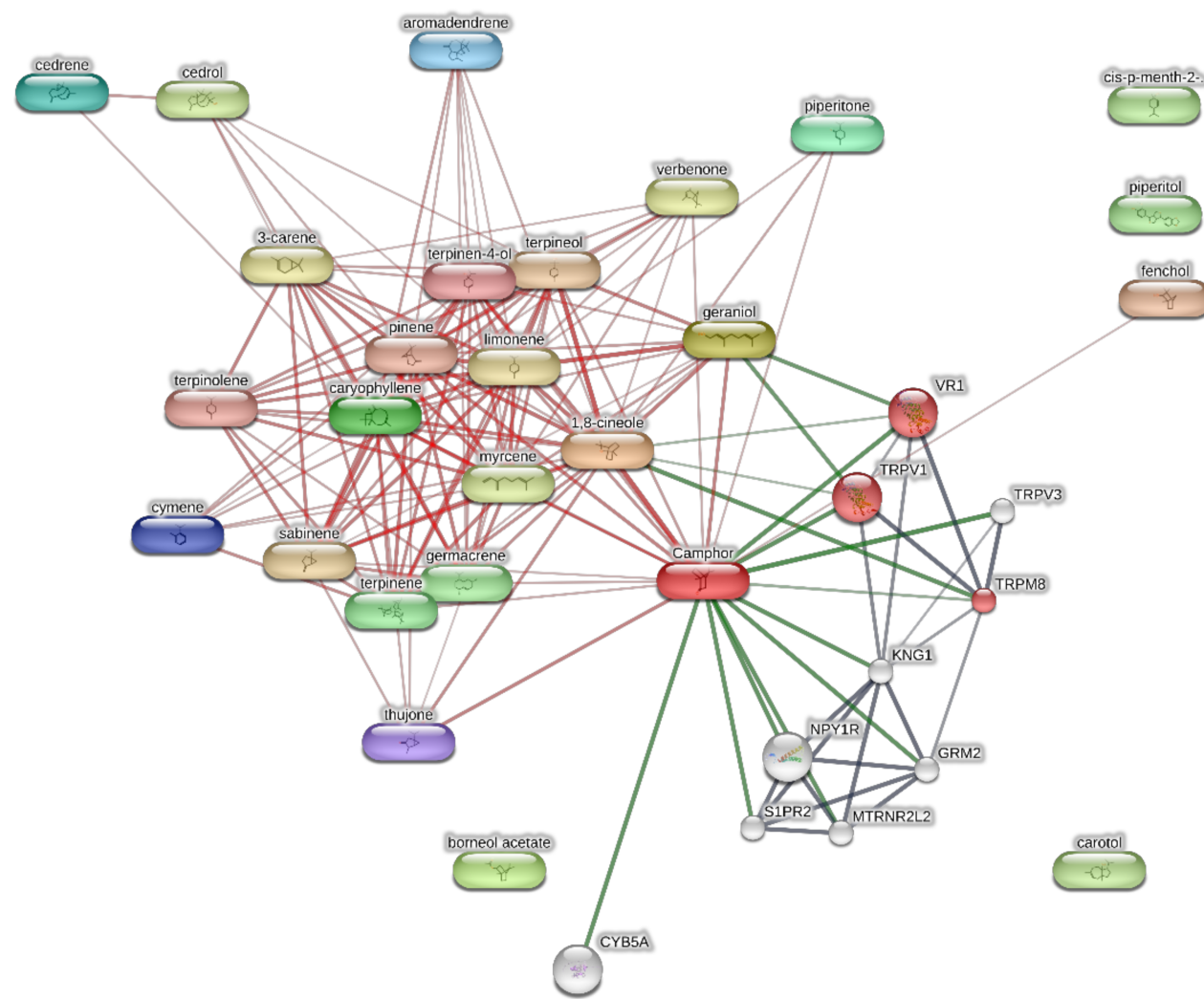

Figure 8. Target component analyses conducted on the bioinformatics platform STITCH for predicting putative proteins targeted by terpene compounds from the hydrosols of rosemary (A), sage (B) and cypress $(\mathbf{C})$. The gene ontology analysis showed the probability of human thermoception pathway (GO: 0050955) modulation by different phytocompounds, including camphor, geraniol, 1,8-cineole, and fenchol.

\section{Discussion}

\subsection{Phytochemical Analysis}

Results obtained from the chemical analysis showed in all hydrolates the presence of more polar compounds, mainly oxygenated monoterpenes, compared with the other classes of VOCs; this is in accordance with our previous report [8]. On the basis of GC-MS data, 1,8-cineole (eucalyptol) appears to be the most abundant constituent in rosemary and sage extracts (47.1\% and $42.9 \%$ ), while 4-terpineol is the most abundant in the cypress hydrosol. In sage, the amount of $\alpha$ - and $\beta$-thujone is also relevant $(24.3 \%$ and $14.7 \%)$. This is in agreement with the results obtained by NMR analysis, where the signals of these compounds are well detected in the corresponding spectra (Figure 1). The NMR data of rosemary hydrosol, however, also show a relevant amount of verbenone that appears comparable to 1,8-cineole, while in sage hydrosol, camphor appears in a comparable amount to $\alpha / \beta$-thujone (both isomers are undistinguished via NMR analysis). Results obtained by LC-MS analyses confirmed NMR hydrolate fingerprints, especially regarding the most abundant compounds, even if some minor polar volatiles were also detected. Such semi-quantitative considerations are, therefore, in disagreement with the semi-quantitative data obtained via GC-MS, where verbenone in rosemary is $2.8 \%$, while camphor is $5.4 \%$ and $8.9 \%$ in rosemary and sage, respectively. This evidence could be due to the different ionization of each molecule, which is known to be strictly related to its chemical structure. The efficacy of the MS-based methods for rapid semi-quantitative analysis of crude extracts such as the hydrosols here analyzed appears, therefore, lower compared to the NMR methods. This highlights the relevance of applying different spectroscopic methods in order to obtain a more exhaustive picture of the overall phytochemical fingerprint of the 
hydrosols. In this case, the NMR technique, in particular, could represent a better option to rapidly obtain potentially useful quantitative information and distinguish samples in larger datasets in combination with chemometric analysis.

\subsection{Biological Activity}

In the allelopathy and brine shrimp lethality tests, rosemary hydrosol appeared more toxic than sage and cypress extracts. This effect could be related, albeit partially, to the presence of 1,8-cineole, which was already described as a root growth inhibitor [35]; 1,8-cineole represented the main constituent not only of rosemary but also of sage hydrosol. Other constituents present in rosemary hydrosol should therefore contribute, possibly acting synergistically with 1,8-cineole, to its stronger allelopathy activity and brine shrimp toxicity compared to the sage hydrosol. It is worthy to note that the overall amount of monoterpene hydrocarbons is much higher in rosemary than sage hydrosol $(15.6 \%$ and $1.3 \%$, respectively); moreover, only $86.7 \%$ of the compounds in rosemary hydrosol were identified, while in sage, nearly all of them were determined (99.6\%). The presence of higher amounts of monoterpenes or even other unidentified compounds could be responsible for the higher toxicity of rosemary hydrosol compared to sage. Concerning the antifungal activity, the presence of 1,8-cineole, camphor, and camphene in rosemary and sage hydrosols could be related, albeit partially, to their efficacy compared to the cypress hydrosol as mycostatic agents [36,37].

Considering the analysis on the hypothalamic cell line (Hypo-E22), only the sage hydrosol showed a viability reduction that appears concentration-dependent; this result could be due to the presence of $\alpha$ - and $\beta$-thujone, which are known to be neurotoxic derivatives [38]. Moreover, rosemary and sage were more effective than cypress in blunting the hydrogen peroxide-induced toxicity, thus restoring the basal viability levels. Particularly, the observed protective effects on hypothalamic cells occurred at hydrosol concentrations below the cytotoxic concentration $(100 \mu \mathrm{g} / \mathrm{mL})$ observed in the HCT116 cell line. These results, combined together, suggest that the rosemary hydrosol appears to be the best recommended extract at the neuronal level, being at the same time non-toxic in the concentration range of $5-50 \mu \mathrm{g} / \mathrm{mL}$ for hypothalamic cells and protective against hydrogen peroxide-induced toxicity. This is in line with the data on the beneficial properties on cognition and the cerebrovascular system of rosemary aromatic water observed in healthy adults [14].

Regarding the bioinformatics analysis, TRPM8, TRPV1, and VR1 were highlighted by the platform as putative targets with high scores (0.916-0.918). These receptors were detected in both the hypothalamus and colon. In the colon, they could mediate antiproliferative and anti-inflammatory effects [39-41], thus supporting the observed cytotoxic effects on HCT116 cells, especially at the highest tested concentrations. In the hypothalamus, these receptors are mainly involved in neuromodulatory and neuroendocrine effects [42-45]. In this regard, we hypothesize that the hydrolates' neuroprotective effects towards HypoE22 could be due, albeit partially, to their intrinsic antiradical effects.

\section{Materials and methods}

\subsection{Chemicals}

UHPLC-grade acetonitrile, formic acid, and water were purchased from Romil-Deltek (Italy). Borneol, camphor, 1,8-cineole, linalool, $\alpha$-terpineol, 4-terpineol, $\alpha$ - and $\beta$-thujone, and verbenone, used as reference standards for UHPLC-MS analyses, were purchased from Sigma-Aldrich (Milano, Italy).

\subsection{Plant Cultivation and Samples Preparation}

Cypress (Cupressus sempervirens L.), rosemary (Salvia rosmarinus Spenn. syn. Rosmarinus officinalis L.), and sage (Salvia officinalis L.) were grown following biodynamic agricultural principles [46] in the agro-farm "Le Tassinaie", which consists of a main house surrounded by 3 hectares of land mostly dedicated to agricultural activities. This agro-farm 
is located in the territory of Castellina Marittima within the district of Pisa in the Tuscany region, Italy. The woody cones of cypress (ca. $7 \mathrm{~kg}$ ) and the flowering aerial parts of rosemary and sage (both ca. $3 \mathrm{~kg}$ ) were manually collected in February, April, and June 2020, respectively. The fresh plant materials were distilled using the TredTechnology extractor of essential oils, model EOE20. In all cases, the plant materials were immersed in $4 \mathrm{~L}$ of tap water and distilled under vacuum at 0.4 bar and $85^{\circ} \mathrm{C}$ for $1 \mathrm{~h}$, obtaining in all cases around $1 \mathrm{~L}$ of the corresponding aromatic water; the corresponding essential oils obtained during the distillation process were removed from the top of the aromatic water with a glass syringe. It is important to note that these distillation conditions were optimized in order to obtain the aromatic waters as main products of such a manufacturing procedure, rather than as by-products, as discussed in-depth in a previous work [8].

\subsection{HS-SPME-GC/MS Analysis}

An SPME device coated with polydimethylsiloxane (PDMS, $100 \mu \mathrm{m}$ ) was obtained from Supelco. The fiber, conditioned according to the manufacturer's recommendations, was exposed to the headspace of the hydrosols for $30 \mathrm{~s}$, withdrawn into the needle and immediately transferred to the injection port of the GC/MS, where the fiber was desorbed with a splitless injection method. The gas chromatograph was an Agilent 7890B equipped with an Agilent HB-5MS (Agilent Technologies Inc., Santa Clara, CA, USA) capillary column $(30 \mathrm{~m} \times 0.25 \mathrm{~mm}$; coating thickness $0.25 \mu \mathrm{m})$. The analytical conditions were as follows: injector and transfer line temperatures were $250^{\circ} \mathrm{C}$ and $240{ }^{\circ} \mathrm{C}$, respectively; the oven temperature was programmed from 60 to $240^{\circ} \mathrm{C}$ at $3{ }^{\circ} \mathrm{C} / \mathrm{min}$; carrier gas helium was set at $1 \mathrm{~mL} / \mathrm{min}$. The gas chromatograph-electron impact mass spectrometer (GC-EIMS) was an Agilent 5977B single quadrupole mass detector (Agilent Technologies Inc., Santa Clara, CA, USA). Acquisition was performed in full scan within a 30-300 $\mathrm{m} / \mathrm{z}$ range, with a scan time of $1.0 \mathrm{~s}$.

\subsection{NMR Analysis}

${ }^{1} \mathrm{H}-\mathrm{NMR}$ spectra were obtained on a Bruker Avance III $400 \mathrm{MHz}$ spectrometer. Rosemary, sage, and cypress samples were prepared by adding $60 \mu \mathrm{L}$ of $\mathrm{D}_{2} \mathrm{O}$ as an internal lock to $600 \mu \mathrm{L}$ of each hydrolate. Pre-saturation was carried out with a relaxation delay ( $\mathrm{d} 1=2 \mathrm{~s})$ and mixing time ( $(\mathrm{d} 18=0.8 \mathrm{~s})$. In both cases, the number of scans was 64 , and partial suppression of the solvent signals around $4.80 \mathrm{ppm}$ was achieved.

\subsection{UHPLC-HR-ESI-MS/MS Analysis}

The UHPLC-HR-MS system was composed of a Vanquish Flex Binary pump LC and a $\mathrm{Q}$ Exactive Plus MS equipped with an electrospray ionization (ESI) source, the Orbitrap-based FT-MS system (Thermo Fischer Scientific Inc., Dreieich, Germany). The chromatography was performed on a Kinetex Biphenyl column $(100 \times 2.1 \mathrm{~mm}, 2.6 \mu \mathrm{m}$ particle size) composed of SecurityGuardTM Ultra Cartridges (Phenomenex, Bologna, Italy). Elution was carried out with formic acid in $\mathrm{H}_{2} \mathrm{O} 0.1 \% v / v$ (solvent $\mathrm{A}$ ) and formic acid in acetonitrile $0.1 \% v / v$ (solvent $\mathrm{B}$ ) with a linear solvent gradient ( 5 to $60 \%$ B within $16 \mathrm{~min})$. Samples $(5 \mu \mathrm{L})$ were injected into the $\mathrm{LC}$ system at a flow rate of $0.5 \mathrm{~mL} / \mathrm{min}$, maintaining autosampler and column oven temperatures at 4 and $35^{\circ} \mathrm{C}$, respectively. MS parameters were applied as previously reported [8].

\subsection{Biological Analysis}

\subsubsection{Allelopathy Test}

Commercial seeds of three lettuce varieties, namely Romana, Lollo Bionda, and Canasta, were selected for the test due to their fast germination rate and sensitivity. According to the method detailed in our previous paper [47], seeds were distributed on paper beds in a Petri capsule imbibed with diluted hydrosols (dilution $[v / v]$ in distilled water $1 / 10$ and 1/100). The emergence of at least $2 \mathrm{~mm}$ length with the typical geotropic curvature of the radicle was used as the criterium to define the presence/absence of germination. The 
seeds that showed false germination by soaking were not accounted for. The germination was recorded at 48,72 , and $96 \mathrm{~h}$ by counting the number of germinated seeds and were expressed as the mean value of at least triplicate experiments.

\subsubsection{Brine Shrimp Lethality Test}

The cytotoxicity limits of the extracts in the range of $0.1-20 \mathrm{mg} / \mathrm{mL}$ were evaluated through the brine shrimp Artemia salina lethality bioassay, as previously reported [47]. Briefly, cysts of Artemia salina were hatched in artificial seawater ( 1 g cysts/L). After $24 \mathrm{~h}$, living brine shrimp were distributed in a 6 well-plate in the presence of diluted plant hydrosols (500-10 $\mu \mathrm{L} / \mathrm{mL})$ in artificial seawater, and $24 \mathrm{~h}$ later, the living/dead organisms were monitored. The experiments were carried out in triplicate.

\subsubsection{Antifungal Activity}

The in vitro antifungal activity of hydrosols were assessed against different yeasts, dermatophyte, and fungal pool species: Candida albicans (YEPGA 6138), C. tropicalis (YEPGA 6184), Arthroderma crocatum (CCF 5300), A. gypseum (CCF 6261), A. quadrifidum (CCF 5792), Trichophyton mentagrophytes (CCF 4823), T. rubrum (CCF 4879), T. erinacei (CCF 5830), and T. tonsurans (CCF 4834), as previously described [48].

\subsubsection{Cell Cultures, Viability Test, and Neuro-Protective Effects}

The effects of the hydrosols $(50-500 \mu \mathrm{L} / \mathrm{mL})$ were preliminarily tested on the human HCT116 cell line (colorectal epithelial carcinoma), and the viability was measured through the 3-(4,5-dimethylthiazol-2-yl)-2,5-diphenyltetrazolium bromide (MTT) test in order to define the cell susceptibility. The detailed experimental conditions were reported in our previous paper [49]. In order to better elucidate a possible effect on the nervous system, a deeper investigation of the potential effects of subtoxic dilutions of hydrosols was conducted on non-tumor hypothalamic rat cells (Hypo-E22). Samples were tested at concentrations ranging from 5 to $50 \mu \mathrm{L} / \mathrm{mL}$, and the biocompatibility was assessed through the MTT cell viability test. The highest concentration that was biocompatible was used to investigate protective effects against the neurotoxicity induced by hydrogen peroxide $(300 \mu \mathrm{M})$. The detailed experimental conditions are reported in our previous paper [50]. Viability data were expressed as variation compared to the control untreated group.

\subsubsection{Inhibition of Horseradish Peroxidase}

The activity of horseradish peroxidase (HRP) can be monitored through the decoloration of the phenol red used as substrate. Each hydrosol was directly tested on a 96-well flat-bottom microplate containing test sample $(10 \mu \mathrm{L}), 10 \mathrm{nM}$ peroxidase enzyme solution $(5 \mu \mathrm{L}), 50 \mu \mathrm{M}$ phenol red $(5 \mu \mathrm{L})$, and $50 \mathrm{mM} \mathrm{pH} 7.4$ phosphate buffer solution $(170 \mu \mathrm{L})$. After incubation for $5 \mathrm{~min}$ in the dark at room temperature, $50 \mu \mathrm{M}$ hydrogen peroxide $(10 \mu \mathrm{L})$ was added. After $10 \mathrm{~min}$, the absorbance was recorded at $\lambda=550 \mathrm{~nm}$, and the percentage inhibition was calculated.

\subsubsection{In Silico Analysis}

Putative targets were identified according to the bioinformatics method recently described by $\mathrm{Gu}$ and colleagues [51]. Briefly, proteins targeted by extracts were predicted using the bioinformatics platform STITCH; the same resource was employed for the network-pharmacology and gene ontology analyses.

\subsubsection{Statistical Analysis}

Statistical analysis was performed using GraphPad Prism version 5.01 for Windows (GraphPad Software, San Diego, CA, USA). Means \pm S.E.M. were determined for each experimental group and analyzed by one-way analysis of variance (ANOVA), followed by Tukey test. Statistical significance was set at $p<0.05$. 


\section{Conclusions}

In the present study, a multidirectional approach was conducted to unravel the phytochemical composition and biological properties of the hydrosols from sage, rosemary, and cypress. Monoterpenes and especially oxygenated monoterpenes represent the most abundant classes in all samples. In the case of rosemary, the presence of 1,8-cineole, camphor, and camphene could be at the basis of its high activity as an antimycotic agent compared to sage and cypress hydrosols. On the other hand, the levels of 1,8-cineole and camphor in rosemary and sage could also be responsible for the higher potency as cytotoxic agents compared to cypress, whereas the very close protective effects exerted by all three hydrosols could be partly due to their intrinsic antiradical properties. The overall experience with these extracts indicates the hydrolates are an important source of relevant phytochemicals with significant pharmacological potential.

On the basis of experimental data, we can speculate a wider range of potential applications for hydrosols, ranging from weed management to the formulation of hygiene-related products, such as for pool management or for body care. Regardless, some limitations of the present study, including the variability of the phytocomplex and hydrodistillation process (solvent/matrix ratio, temperature, pressure, time), suggest that future deeper investigations would be beneficial to confirm the rational base for these innovative applications.

Supplementary Materials: The following supporting information can be downloaded at: https:// www.mdpi.com/article/10.3390/plants11030349/s1, Figure S1: GC-MS chromatogram of rosemary hydrosol headspace; Figure S2: GC-MS chromatogram of sage hydrosol headspace; Figure S3: GC-MS chromatogram of cypress hydrosol headspace.

Author Contributions: Conceptualization, M.P.; methodology, G.A.F., B.M. and M.D.L.; validation, C.F. and P.A.; formal analysis, P.A.; investigation, B.M., M.D.L. and C.F.; resources, L.M. and A.B.; writing-original draft, M.P., G.A.F. and M.D.L.; writing-review and editing, A.B. and L.M.; visualization, M.D.L.; supervision, L.M. and C.F.; funding acquisition, A.B. and L.M. All authors have read and agreed to the published version of the manuscript.

Funding: This research received no external funding.

Acknowledgments: Authors are grateful to Società Agricola "Le Tassinaie" located in Tuscany, Italy, for providing rosemary, sage, and cypress aromatic waters. The article is part of the third mission activities of the Botanic Garden "Giardino dei Semplici" planned for the 20th anniversary of the establishment.

Conflicts of Interest: The authors declare no conflict of interest.

\section{References}

1. ANSM. Eaux distillées végétales et eaux aromatisées végétales, 11th ed.; ANSM Pharmacopeé Française: Saint-Denis, France, 2012.

2. D'Amato, S.; Serio, A.; López, C.C.; Paparella, A. Hydrosols: Biological activity and potential as antimicrobials for food applications. Food Control 2018, 86, 126-137. [CrossRef]

3. Inouye, S.; Takahashi, M.; Abe, S. A comparative study on the composition of forty four hydrosols and their essential oils. Int. J. Essent. Oil Ther. 2008, 2, 89-104.

4. Nanashima, N.; Kitajima, M.; Takamagi, S.; Fujioka, M.; Tomisawa, T. Comparison of chemical composition between kuromoji (Lindera umbellata) essential oil and hydrosol and determination of the deodorizing effect. Molecules 2020, 25, 4195. [CrossRef] [PubMed]

5. Francezon, N.; Stevanovic, T. Chemical composition of essential oil and hydrosol from Picea mariana bark residue. BioResources 2017, 12, 2635-2645. [CrossRef]

6. Śmigielski, K.B.; Prusinowska, R.; Krosowiak, K.; Sikora, M. Comparison of qualitative and quantitative chemical composition of hydrolate and essential oils of lavender (Lavandula angustifolia). J. Essent. Oil Res. 2013, 25, 291-299. [CrossRef]

7. Di Vito, M.; Smolka, A.; Proto, M.R.; Barbanti, L.; Gelmini, F.; Napoli, E.; Bellardi, M.G.; Mattarelli, P.; Beretta, G.; Sanguinetti, M.; et al. Is the antimicrobial activity of hydrolates lower than that of essential oils? Antibiotics 2021, 10, 88. [CrossRef]

8. Politi, M.; Menghini, L.; Conti, B.; Bedini, S.; Farina, P.; Cioni, P.L.; Braca, A.; De Leo, M. Reconsidering hydrosols as main products of aromatic plants manufactory: The lavandin (Lavandula $\times$ intermedia) case study in Tuscany. Molecules 2020, $25,2225$. [CrossRef] 
9. Paolini, J.; Leandri, C.; Desjobert, J.M.; Barboni, T.; Costa, J. Comparison of liquid-liquid extraction with headspace methods for the characterization of volatile fractions of commercial hydrolats from typically Mediterranean species. J. Chromatogr. A 2008, 1193, 37-49. [CrossRef]

10. Tomi, K.; Kitao, M.; Konishi, N.; Murakami, H.; Matsumura, Y.; Hayashi, T. Enantioselective GC-MS analysis of volatile components from rosemary (Rosmarinus officinalis L.) essential oils and hydrosols. Biosci. Biotechnol. Biochem. 2016, 80, 840-847. [CrossRef]

11. Elamrani, A.; Zrira, S.; Benjilali, B.; Berrada, M. A study of moroccan rosemary oils. J. Essent. Oil Res. 2000, 12, 487-495. [CrossRef]

12. Tornuk, F.; Cankurt, H.; Ozturk, I.; Sagdic, O.; Bayram, O.; Yetim, H. Efficacy of various plant hydrosols as natural food sanitizers in reducing Escherichia coli O157:H7 and Salmonella typhimurium on fresh cut carrots and apples. Int. J. Food Microbiol. 2011, 148, 30-35. [CrossRef] [PubMed]

13. Ozturk, I.; Tornuk, F.; Caliskan-Aydogan, O.; Durak, M.Z.; Sagdic, O. Decontamination of iceberg lettuce by some plant hydrosols. LWT-Food Sci. Technol. 2016, 74, 48-54. [CrossRef]

14. Moss, M.; Smith, E.; Milner, M.; McCready, J. Acute ingestion of rosemary water: Evidence of cognitive and cerebrovascular effects in healthy adults. J. Psychopharmacol. 2018, 32, 1319-1329. [CrossRef] [PubMed]

15. Baydar, H.; Sangun, M.K.; Erbas, S.; Kara, N. Comparison of aroma compounds in distilled and extracted products of sage (Salvia officinalis L.). J. Essent. Oil-Bear. Plants 2013, 16, 39-44. [CrossRef]

16. Aazza, S.; Lyoussi, B.; Miguel, M.G. Antioxidant activity of some Morrocan hydrosols. J. Med. Plants Res. 2011, 5, $6688-6696$.

17. Rawat, P.; Khan, M.F.; Kumar, M.; Tamarkar, A.K.; Srivastava, A.K.; Arya, K.R.; Maurya, R. Constituents from fruits of Cupressus sempervirens. Fitoterapia 2010, 81, 162-166. [CrossRef] [PubMed]

18. Nafila, Z.; Cherifa, B.; Carlos, C.; Boubekeur, N.; Mohamed, Y. Identification of volatile compounds, antimicrobial properties and antioxidant activity from leaves, cones and stems of Cupressus sempervirens from Algeria. Afr. J. Microbiol. Res. 2015, 9, 83-90. [CrossRef]

19. Tavares, C.S.; Martins, A.; Faleiro, M.L.; Miguel, M.G.; Duarte, L.C.; Gameiro, J.A.; Roseiro, L.B.; Figueiredo, A.C. Bioproducts from forest biomass: Essential oils and hydrolates from wastes of Cupressus lusitanica Mill. and Cistus ladanifer L. Ind. Crops Prod. 2020, 144, 112034. [CrossRef]

20. Aazza, S.; Lyoussi, B.; Miguel, M.G. Antioxidant activity of eight hydrosols from Morocco. Asian J. Plant Sci. 2012, 11, 137-142. [CrossRef]

21. Rašković, A.; Milanović, I.; Pavlović, N.; Ćebović, T.; Vukmirović, S.; Mikov, M. Antioxidant activity of rosemary (Rosmarinus officinalis L.) essential oil and its hepatoprotective potential. BMC Complement. Altern. Med. 2014, 14, 225. [CrossRef]

22. Jiang, Y.; Wu, N.; Fu, Y.; Wang, W.; Luo, M.; Zhao, C.; Zu, Y.; Liu, X. Chemical composition and antimicrobial activity of the essential oil of rosemary. Environ. Toxicol. Pharmacol. 2011, 32, 63-68. [CrossRef]

23. Lo Presti, M.; Ragusa, S.; Trozzi, A.; Dugo, P.; Visinoni, F.; Fazio, A.; Dugo, G.; Mondello, L. A comparison between different techniques for the isolation of rosemary essential oil. J. Sep. Sci. 2005, 28, 273-280. [CrossRef] [PubMed]

24. El Euch Kammoun, S.; Hassine, D.; Cazaux, S.; Bouzouita, N.; Bouajila, J. Salvia officinalis essential oil: Chemical analysis and evaluation of antienzymatic and antioxidant bioactivities. S. Afr. J. Bot. 2019, 120, 253-260. [CrossRef]

25. Craft, J.; Satyal, P.; Setzer, W. The chemotaxonomy of common sage (Salvia officinalis) based on the volatile constituents. Medicines 2017, 4, 47. [CrossRef] [PubMed]

26. Abu-Darwish, M.; Cabral, C.; Ferreira, I.; Gonçalves, M.; Cavaleiro, C.; Cruz, M.; Al-bdour, T.; Salgueiro, L. Essential oil of common sage (Salvia officinalis L.) from Jordan: Assessment of safety in mammalian cells and its antifungal and anti-inflammatory potential. BioMed Res. Int. 2013, 2013, 538940. [CrossRef] [PubMed]

27. Selim, S.; Adam, M.; Hassan, S.; Albalawi, A. Chemical composition, antimicrobial and antibiofilm activity of the essential oil and methanol extract of the Mediterranean cypress (Cupressus sempervirens L.). BMC Complement. Altern. Med. 2014, 14, 179. [CrossRef] [PubMed]

28. Ismail, A.; Lamia, H.; Mohsen, H.; Samia, G.; Bassem, J. Chemical composition, bio-herbicidal and antifungal activities of essential oils isolated from Tunisian common cypress (Cupressus sempervirens L.). J. Med. Plants Res. 2013, 7, 1070-1080.

29. Lee, S.; Do, H.; Min, K. Effects of essential oil from Hinoki cypress, Chamaecyparis obtusa, on physiology and behavior of flies. PLoS ONE 2015, 10, e0143450. [CrossRef]

30. Sirisoma, N.S.; Hoeld, K.M.; Casida, J.E. $\alpha$ - and $\beta$-Thujones (herbal medicines and food additives): Synthesis and analysis of hydroxy and dehydro metabolites. J. Agric. Food Chem. 2001, 49, 1915-1921. [CrossRef]

31. Gurudutt, K.; Pasha, M.; Ravindranath, B.; Srinivas, P. Reactions of oxiranes with alkali metals: Intermediacy of radical anions. Tetrahedron 1984, 40, 1629-1632. [CrossRef]

32. Jain, S.; Sharma, V.; Sain, B. Highly efficient and selective oxidation of secondary alcohols to ketones under organic solvent and transition metal free conditions. Tetrahedron 2006, 62, 6841-6847. [CrossRef]

33. Ashnagar, A.; Gharib Naseri, N.; Bayemani, A. Isolation and determination of the major chemical compounds present in essential oil of the leaves of Myrtus plant grown in Khuzestan province of Iran. Asian J. Chem. 2009, 21, 4969-4975.

34. Allal, B.A.; El Firdoussi, L.; Allaoud, S.; Karim, A.; Castanet, Y.; Mortreux, A. Catalytic oxidation of $\alpha$-pinene by transition metal using $t$-butyl hydroperoxide and hydrogen peroxide. J. Mol. Catal. A Chem. 2003, 200, 177-184. [CrossRef]

35. Koitabashi, R.; Suzuki, T.; Kawazu, T.; Sakai, A.; Kuroiwa, H.; Kuroiwa, T. 1,8-Cineole inhibits root growth and DNA synthesis in the root apical meristem of Brassica campestris L. J. Plant Res. 1997, 110, 1-6. [CrossRef] [PubMed] 
36. Tirillini, B.; Velasquez, E.; Pellegrino, R. Chemical composition and antimicrobial activity of essential oil of Piper angustifolium. Planta Med. 1996, 62, 372-373. [CrossRef]

37. Bouzabata, A.; Cabral, C.; Gonçalves, M.; Cruz, M.; Bighelli, A.; Cavaleiro, C.; Casanova, J.; Tomi, F.; Salgueiro, L. Myrtus communis L. as source of a bioactive and safe essential oil. Food Chem. Toxicol. 2015, 75, 166-172. [CrossRef]

38. Zámboriné Németh, É.; Thi Nguyen, H. Thujone, a widely debated volatile compound: What do we know about it? Phytochem. Rev. 2020, 19, 405-423. [CrossRef]

39. Borrelli, F.; Pagano, E.; Romano, B.; Panzera, S.; Maiello, F.; Coppola, D.; De Petrocellis, L.; Buono, L.; Orlando, P.; Izzo, A Colon carcinogenesis is inhibited by the TRPM8 antagonist cannabigerol, a Cannabis-derived non-psychotropic cannabinoid. Carcinogenesis 2014, 35, 2787-2797. [CrossRef]

40. Sung, B.; Prasad, S.; Ravindran, J.; Yadav, V.; Aggarwal, B. Capsazepine, a TRPV1 antagonist, sensitizes colorectal cancer cells to apoptosis by TRAIL through ROS-JNK-CHOP-mediated upregulation of death receptors. Free Radic. Biol. Med. 2012, 53, 1977-1987. [CrossRef]

41. Yang, X.; Han, J.; Liu, R. Effects of experimental colitis on the expressions of calcitonin gene-related peptide and vanilloid receptor 1 in rat spinal cord sensory neurons. Sheng Li Xue Bao 2008, 60, 143-148.

42. Li, D.; Chen, S.; Pan, H. VR1 receptor activation induces glutamate release and postsynaptic firing in the paraventricular nucleus J. Neurophysiol. 2004, 92, 1807-1816. [CrossRef] [PubMed]

43. Surkin, P.; Dmytrenko, G.; Di Giorgio, N.; Bizzozzero, M.; De Laurentiis, A.; Fernández-Solari, J. Participation of TRPV1 in the activity of the GnRH system in male rats. Eur. J. Neurosci. 2020, 52, 2995-3001. [CrossRef] [PubMed]

44. Singh, R.; Bansal, Y.; Sodhi, R.; Khare, P.; Bishnoi, M.; Kondepudi, K.; Medhi, B.; Kuhad, A. Role of TRPV1/TRPV3 channels in olanzapine-induced metabolic alteration: Possible involvement in hypothalamic energy-sensing, appetite regulation, inflammation and mesolimbic pathway. Toxicol. Appl. Pharmacol. 2020, 402, 115124. [CrossRef] [PubMed]

45. Ordás, P.; Hernández-Ortego, P.; Vara, H.; Fernández-Peña, C.; Reimúndez, A.; Morenilla-Palao, C.; Guadaño-Ferraz, A.; Gomis, A.; Hoon, M.; Viana, F.; et al. Expression of the cold thermoreceptor TRPM8 in rodent brain thermoregulatory circuits. J. Comp. Neurol. 2021, 529, 234-256. [CrossRef]

46. Turinek, M.; Grobelnik-Mlakar, S.; Bavec, M.; Bavec, F. Biodynamic agriculture research progress and priorities. Renew. Agric. Food Syst. 2009, 24, 146-154. [CrossRef]

47. Ferrante, C.; Recinella, L.; Ronci, M.; Menghini, L.; Brunetti, L.; Chiavaroli, A.; Leone, S.; Di Iorio, L.; Carradori, S.; Tirillini, B.; et al Multiple pharmacognostic characterization on hemp commercial cultivars: Focus on inflorescence water extract activity. Food Chem. Toxicol. 2019, 125, 452-461. [CrossRef]

48. Angelini, P.; Matei, F.; Flores, G.; Pellegrino, R.; Vuguziga, L.; Venanzoni, R.; Tirillini, B.; Emiliani, C.; Orlando, G.; Menghini, L.; et al. Metabolomic profiling, antioxidant and antimicrobial activity of Bidens pilosa. Processes 2021, 9, 903. [CrossRef]

49. Orlando, G.; Leone, S.; Ferrante, C.; Chiavaroli, A.; Mollica, A.; Stefanucci, A.; Macedonio, G.; Dimmito, M.; Leporini, L.; Menghini, L.; et al. Effects of kisspeptin-10 on hypothalamic neuropeptides and neurotransmitters involved in appetite control. Molecules 2018, 23, 3071. [CrossRef]

50. di Giacomo, V.; Recinella, R.; Chiavaroli, A.; Orlando, G.; Cataldi, A.; Rapino, M.; Di Valerio, V.; Politi, M.; Antolini, M.; Acquaviva, A.; et al. Metabolomic profile and antioxidant/anti-inflammatory effects of industrial hemp water extract in fibroblasts, keratinocytes and isolated mouse skin specimens. Antioxidants 2021, 10, 44. [CrossRef]

51. Gu, L.; Lu, J.; Li, Q.; Wu, N.; Zhang, L.; Li, H.; Xing, W.; Zhang, X. A network-based analysis of key pharmacological pathways of Andrographis paniculata acting on Alzheimer's disease and experimental validation. J. Ethnopharmacol. 2020, 251, 112488. [CrossRef] 